\title{
Possibility of Use of NCC. Reinforced Melamine-Urea- Formaldehyde Adhesive in Plywood Manufacturing
}

\section{Mogućnost uporabe melamin-urea- formaldehidnog ljepila ojačanog nanocelulozom u proizvodnji furnirskih ploča}

\author{
Original scientific paper • Izvorni znanstveni rad \\ Received-prispjelo: 2. 7. 2020. \\ Accepted-prihvaćeno: 26. 5. 2021. \\ UDK: $630 * 832.282 ; 630 * 861.152 ; 630 * 861.156$ \\ https://doi.org/10.5552/drvind.2021.2029
}

(C) 2021 by the author(s). Licensee Faculty of Forestry and Wood Technology, University of Zagreb. This article is an open access article distributed under the terms and conditions of the Creative Commons Attribution (CC BY) license.

\begin{abstract}
The possibility of using nanocellulose (NCC) as a filling substance for melamine-urea-formaldehyde (MUF) adhesive was investigated for the process of manufacturing plywood. The adhesive mixtures were prepared with various nanocellulose concentrations. The amount of introduced filler had a significant effect on both resin and plywood characteristics. Fourier transform infrared spectroscopy (FTIR) did not show any major changes between experimental and reference variants. The viscosity of resin increased after the introduction of nanocellulose. The addition of NCC in the amount of $5 \mathrm{~g}$ and $10 \mathrm{~g}$ per $100 \mathrm{~g}$ of solid resin led to an improvement in bonding quality, modulus of elasticity and bending strength. Further increase of NCC concentration caused a deterioration of manufactured plywood properties. In summary, the addition of proper amount of nanocellulose resulted in manufacturing plywood with improved properties.
\end{abstract}

Keywords: plywood; melamine-urea-formaldehyde adhesive; nanocellulose; filler

\begin{abstract}
SAŽETAK • U radu je prikazano istraživanje mogućnosti uporabe nanoceluloze (NCC) kao punila za melaminurea-formaldehidno ljepilo (MUF) koje se upotrebljava u proizvodnji furnirskih ploča. Smjese ljepila pripremljene su dodavanjem različitih koncentracija nanoceluloze. Količina dodanog punila znatno je utjecala na svojstva smole i furnirske ploče. Furierovom infracrvenom spektroskopijom (FTIR) nisu utvrđene veće promjene između eksperimentalnih i referentnih varijanti. Viskoznost smole povećala se nakon dodatka nanoceluloze. Dodatak 5 i $10 \mathrm{~g}$ nanoceluloze na $100 \mathrm{~g}$ otvrdnute smole rezultirao je poboljšanjem kvalitete vezanja, modula elastičnosti $i$ čvrstoće na savijanje. Daljnje povećanje koncentracije nanoceluloze uzrokovalo je pogoršanje svojstava proizvedenih furnirskih ploča. Ukratko, dodatak odgovarajuće količine nanoceluloze rezultirao je furnirskom pločom poboljšanih svojstava.
\end{abstract}

Ključne riječi: furnirska ploča; melamin-urea-formaldehidno ljepilo; nanoceluloza; punilo

\footnotetext{
Authors are researchers at Poznan University of Life Sciences, Faculty of Forestry and Wood Technology, Department of Wood-Based Materials, Poznan, Poland.

${ }^{2}$ Author is researcher at Poznan University of Life Sciences, Faculty of Forestry and Wood Technology, Department of Chemistry, Poznan, Poland.
} 


\section{INTRODUCTION}

\section{UVOD}

Nanotechnology is a relatively new science that has already become the frontier of the $21^{\text {st }}$ century. It is defined as the field focused on the control and understanding of the matter at a dimensional range between 1 and $100 \mathrm{~nm}$ (Hulla et al., 2015). From the beginning, nanotechnology has been playing the role of a scientific platform joining and linking together various disciplines (Szczesna-Antczak et al., 2012). The objects with the dimensions between 1 and $100 \mathrm{~nm}$ have unique mechanical, optical, magnetic and electrical properties (Wegner and Jones, 2005). Thus, the nanoscience also provides many opportunities for woodbased materials manufacturing (Candan and Akbulut, 2013). It seeks to develop advanced materials having significantly improved chemical, physical properties and functions (Wegner and Jones, 2006).

Wood-based materials such as plywood, particleboards, medium- and high density fiberboards are becoming more popular in recent years. The production of plywood, which is a multilayer composite made of glued wood veneers, reached about 157 million $\mathrm{m}^{3}$ in 2017 and it is still growing (Bekhta et al., 2020; Sydor et al., 2020). Due to its favorable mechanical properties and dimensional stability, it founds an application in many industry branches (Kawalerczyk et al., 2019a). In structural applications, plywood is used in walls, ceilings and roof constructions; in furniture as a basic material for both upholstered and case furniture (Bekhta et al., 2009b; Majewski, 2019). Moreover, it is also appreciated as a packaging material due to its ease of processing, lightness and durability, and in transport as a flooring material or in trailers construction. The properties of plywood and consequently its application depend on the quality of veneers and the type of used adhesive (Kawalerczyk et al., 2020c; Mirski et al., 2011).

Amino resins are synthetic adhesives widely used in wood-based material industry. Their participation in the general range of wood adhesives market is estimated at $85 \%$ (Jóźwiak, 2018; Kamoun et al., 2003). The three main types: UF (urea-formaldehyde), MF (melamine-formaldehyde) and MUF (melamineurea-formaldehyde) may be distinguished as the most commercially available (Gonçalves et al., 2019; Mirski et al., 2020). The widespread use of MUF adhesives in recent years results from the higher bond quality, water resistance and lower formaldehyde emission in comparison with UF resin (Lei and Frazier, 2015; Tohmura et al., 2001). The adhesives mixtures applied in plywood manufacturing have to contain various kinds of fillers. They are insoluble, non-volatile substances added in order to adjust the viscosity, reduce raw material costs and increase bonding between the wood components (Kawalerczyk et al., 2019b; Ong et al., 2018).

In recent years an interesting concept of using cellulose as a modifier for polymers has been increasingly investigated. It is the most important constituent of the plants cell walls and, moreover, it is also synthe- sized in tunicate sea animals and some bacteria (Henriksson and Berglund, 2007; Janardhnan and Sain, 2011). The attention received by cellulosic particles results from their high surface area, high stiffness and strength. Many studies on using nanocellulose (NCC) as an environmentally friendly modifier of wood adhesives have already been carried out (Ayrilmis et al., 2016a; Gardner et al., 2008; Vineeth et al., 2019).

The effect of nanocellulose addition to amino resins was investigated by Veigel et al. (2012). They found that the modification increased the viscosity of liquid adhesive and caused a significant improvement in both particleboard and oriented strand board (OSB) strength properties. Studies conducted by Mahrdt et al. (2016) confirmed that the introduction of cellulosic particles led to the increase in particleboard strength values. Furthermore, the influence of nanocellulose on multilayered wood-based material has also been investigated. Zhang et al. (2011) noted a major enhancement in plywood shear strength and the reduction in formaldehyde emission because of the silanized nanocellulose added to UF adhesive. However, studies conducted by Kawalerczyk et al. (2020b) did not confirm the effect on the reduction of the harmful formaldehyde emission with the use of non-modified nanocellulose. Ayrilmis et al. (2016b) concluded that cellulosic particles added to UF adhesive can reduce the VOCs (volatile organic compounds) emitted from LVL (laminated veneer lumber). The price of nanocellulose may be a limiting factor for some applications but there are many studies on finding the way to obtain it with more cost-effective methods (Babicka et al., 2020; Kawalerczyk et al., 2021).

Despite the fact that MUF adhesives are becoming more popular, especially for applications in kitchens, floors and some structural materials, and although they are increasingly replacing pure UF adhesives, no studies have examined the effect of their nanocellulose-reinforcement on the properties of manufactured plywood panels (Lei and Frazier, 2015). Thus, the aim of the present study was to investigate the effect of adding NCC to MUF adhesive on the plywood performance.

\section{MATERIALS AND METHODS}

\section{MATERIJALI I METODE}

\subsection{Materials}

2.1. Materijali

Rotary cut birch (Betula L.) veneer sheets were purchased from the market with the dimensions of 320 $\mathrm{mm} \times 320 \mathrm{~mm} \times 1.3 \mathrm{~mm}$, moisture content of $(5 \pm 1)$ $\%$, without any defects, and they were used for the research purpose. The commercial MUF adhesive with the following characteristics: solid content of $64-69$ $\%$, gel time at $100{ }^{\circ} \mathrm{C}$ of $63 \mathrm{~s}$, viscosity between 1000 and $2500 \mathrm{mPa} \cdot \mathrm{s}$, density of $1.27 \mathrm{~g} / \mathrm{m}^{3}$ and $\mathrm{pH}$ of 9.5 10.7 was purchased for the experiment. The $20 \%$ aqueous solution of ammonium nitrate $\left(\mathrm{NH}_{4} \mathrm{NO}_{3}\right)$ was added as a hardener taking into account the environmental aspects (Aras et al., 2015). In order to adjust 
and regulate the viscosity of adhesive mixture, the rye flour was introduced in accordance with the industrial formulations. Nanocellulose, added as a modifier, was purchased from Nanografi Nanotechnology Co. Ltd. (Ankara, Turkey). As declared by the producer, the dimensions of the particles were $300-900 \mathrm{~nm}$ in length and $10-20 \mathrm{~nm}$ in width.

\subsection{Methods}

\subsection{Metode}

A $10 \%$ aqueous suspension of nanocellulose was prepared with the use of magnetic stirrer (600 rpm, 10 min), because cellulosic nanoparticles had to be processed in wet state. The experimental adhesive mixtures with the addition of NCC suspension, flour and hardener were homogenized using CAT-500 homogenizer at $1000 \mathrm{rpm}$ for 2 minutes. The control adhesive was prepared in accordance with an industrial formulation. The compositions of both experimental and reference mixtures are summarized in Table 1.

No additional water was added in experimental variants because the nanocellulose was introduced in the state of water suspension. The viscosities of adhesives mixtures and their changes in $6 \mathrm{~h}$ were investigated using Brookfield DV-II + Pro viscometer. In order to assess the chemical bonding between the resin and nanocellulose, Fourier transform infrared spectroscopy was carried out. Reference and experimental adhesive mixtures were cured at $140^{\circ} \mathrm{C}$ and grinded. The obtained powders with a fraction of $0.125 \mathrm{~mm}$ were mixed with $\mathrm{KBr}$ at $1 / 200 \mathrm{mg}$ ratio. Spectra were registered using a Nicolet iS5 spectrophotometer (Thermo Fisher Scientific) with Fourier transform at the range of $500-4000 \mathrm{~cm}^{-1}$ at the resolution of $4 \mathrm{~cm}^{-1}$, registering 16 scans.

The adhesive mixtures were spread on the surface of external veneers in the amount of $170 \mathrm{~g} / \mathrm{m}^{2}$. The veneer sets were assembled perpendicularly to each other. Three-layer plywood panels with the dimensions of $320 \mathrm{~mm} \times 320 \mathrm{~mm}$ were produced in a hydraulic laboratory press with the following pressing parameters: temperature of $140{ }^{\circ} \mathrm{C}$, unit pressure of $1.3 \mathrm{MPa}$ and pressing time of $4 \mathrm{~min}$. Three replicate panels were produced for all the test groups. Manufactured plywood was tested in order to investigate the following properties:

- formaldehyde (HCHO) emission with the flask method according to EN 717-3 (1996) initially and after 30 days of panels conditioning while left open at $(20 \pm 3){ }^{\circ} \mathrm{C}$ and $(65 \pm 2) \%$ relative humidity,
- shear strength after $24 \mathrm{~h}$ of soaking in water at (20 \pm $3)^{\circ} \mathrm{C}$ and after preparation including boiling in water for $6 \mathrm{~h}$ and cooling in water at $(20 \pm 3){ }^{\circ} \mathrm{C}$ for $1 \mathrm{~h}$ according to EN 314-1 (2004),

- modulus of elasticity and bending strength parallel and perpendicular to the grains of face layer according to EN 310 (1993).

On the basis of the results obtained in above tests, the proper composition of adhesive mixture was selected. The experimental adhesive labeled "N5" showing the best reinforcing effect was applied in the amount of $170,160,150,140$ and $130\left(\mathrm{~g} / \mathrm{m}^{2}\right)$ in order to investigate the possibility of reducing the adhesive consumption in plywood production. The pressing process was conducted at $140{ }^{\circ} \mathrm{C}$ with the unit pressure of 1.3 MPa for $4 \mathrm{~min}$. Manufactured plywood panels were tested in terms of shear strength both after $24 \mathrm{~h}$ of soaking in water at $(20 \pm 3){ }^{\circ} \mathrm{C}$ and after pretreatment consisting of boiling in water for $6 \mathrm{~h}$ and cooling in water at $(20 \pm 3){ }^{\circ} \mathrm{C}$ for $1 \mathrm{~h}$ according to EN 314-1 (2004). The obtained results were compared with a reference variant, which was labeled " 170 REF" in further part of the paper.

The evaluation of mechanical properties and bonding quality involved 12 samples of each variant. The results were subjected to the multivariate statistical analysis ANOVA. The Tukey test with a significance level of $\alpha=0.05$ was applied to distinguish the homogeneous groups with the use of Statistica 13.0 software.

\section{RESULTS}

\section{REZULTATI}

Figure 1 illustrates the time-viscosity dependence. The results indicate that nanocellulose-reinforced MUF resins were characterized by significantly increased viscosity in comparison with reference mixture.

The viscosity of adhesive mixture containing the maximal amount of cellulosic nanoparticles was $46 \%$ and $33 \%$ higher when compared to resin only filled with rye flour initially and after 6 hours of measurements, respectively. The increasing values of all resins viscosity during the test time resulted from the progressive polycondensation reactions and the constant water absorption by hydrophilic fillers. The viscosity of the glue mixture increased with the increasing percentage of nanocellulose addition similarly to investigations reported by Damásio et al. (2017). One factor that may

Table 1 Compositions of adhesive mixtures

Tablica 1. Sastav smjesa ljepila

\begin{tabular}{|c|c|c|c|c|}
\hline \multirow{2}{*}{$\begin{array}{c}\text { Variant label } \\
\text { Oznaka varijante }\end{array}$} & \multicolumn{4}{|c|}{$\begin{array}{c}\text { Quantity (g/100 g of solid MUF resin) } \\
\text { Količina (g/100 g otvrdnute MUF smole) }\end{array}$} \\
\cline { 2 - 5 } & $\begin{array}{c}\text { NCC suspension } \\
\text { NCC suspenzija }\end{array}$ & $\begin{array}{c}\text { Rye flour } \\
\text { Raženo brašno }\end{array}$ & H_O $_{2}$ & $\begin{array}{c}\text { Hardener } \\
\text { Otvrdnjivač }\end{array}$ \\
\hline 0 & 0 & 20 & 10 & 2.5 \\
\hline N5 & 5 & 10 & 0 & 2.5 \\
\hline N10 & 10 & 10 & 0 & 2.5 \\
\hline N15 & 15 & 10 & 0 & 2.5 \\
\hline
\end{tabular}




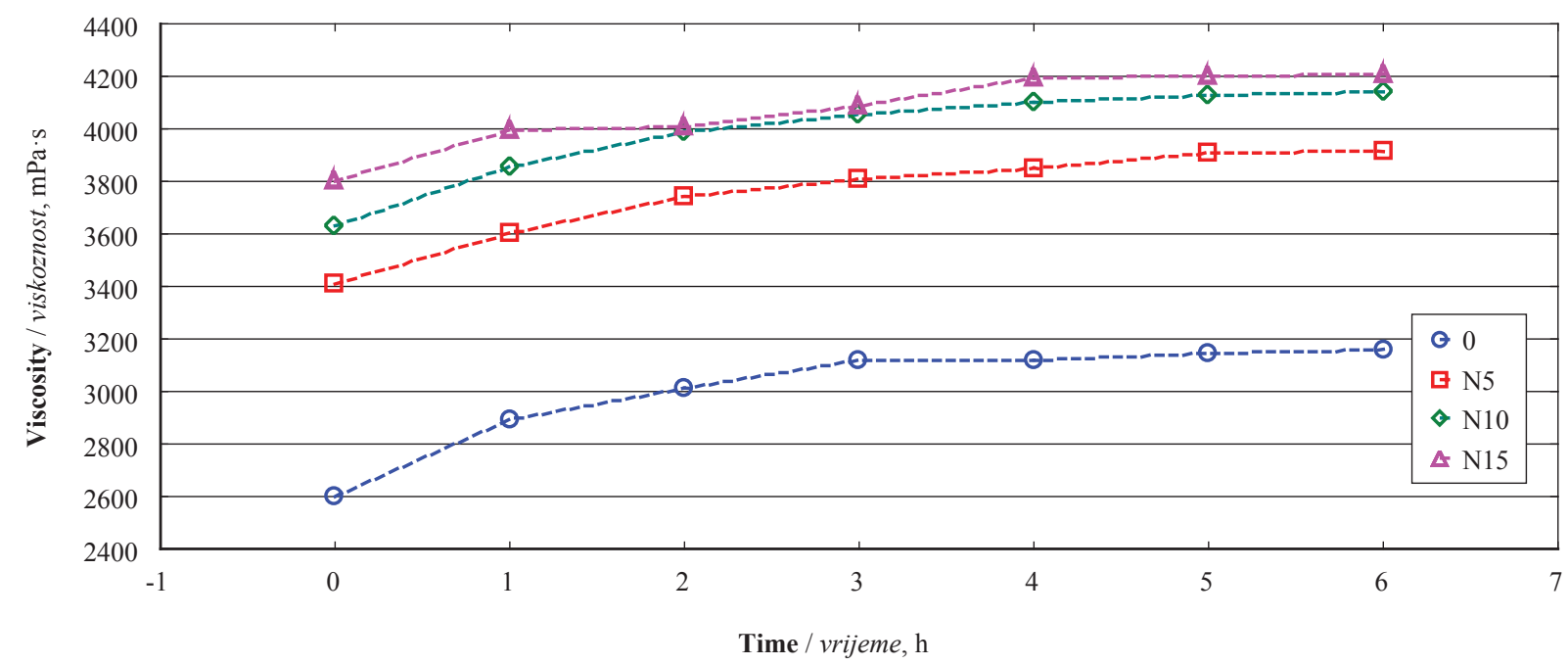

Figure 1 Viscosity of adhesives mixtures

Slika 1. Viskoznost smjesa ljepila

have contributed to this major increase in viscosity is the highly hydrophilic nature of cellulose. It tends to absorb water due to its chemical structure - the surfaces of cellulose are covered in hydroxyl groups on the equatorial positions of glucopyranose ring (Yamane et al., 2006). Another factor is the increased chemical reactivity of nanoparticles in general (Shahbazi et al., 2013). The introduction of nanocellulose probably caused a substantial interfibrillar interaction. The number hydroxyl groups located on the surfaces of individual fibrils can cause a considerable interaction between them, which can lead to the formation of temporary bonds (Iotti et al., 2011).

A similar effect was also observed in case of the NCC-reinforcement of UF and PF adhesives (Kawalerczyk et al., 2020b, a; Mahrdt et al., 2016). Hong and Park (2017) distinguished the viscosity of adhesive as one of the most important factors affecting the strength properties of cured bonds. Studies conducted by Derkyi et al. (2008) also confirmed that the rheological properties of UF resin had a significant effect on plywood bonding quality. The adhesive characterized by too low viscosity penetrates extensively into porous surface of the veneer during application and pressing. Consequently, the layer remaining on the veneer surface is no longer sufficient to ensure good quality of the bond (Sellers, 1985). The viscosity may also be a factor limiting the amount of nanocellulose added to the adhesive. The lack of water in the mixture can affect the crosslinking of adhesive and moreover, the addition of highly hydrophilic filler can prevent water from evaporating during the pressing process (Mahrdt et al., 2016; Réh et al., 2019). Furthermore, it is also hard to evenly spread the adhesive characterized by too high viscosity and adjust it to the applying equipment. In case of this research, both reference and experimental mixtures obtained values that allowed the application without any difficulties.

Since the reinforcing effect of nanocellulose is associated with chemical bonding, the Fourier transform infrared spectroscopy (FTIR) was carried out in order to investigate the chemical interactions. The

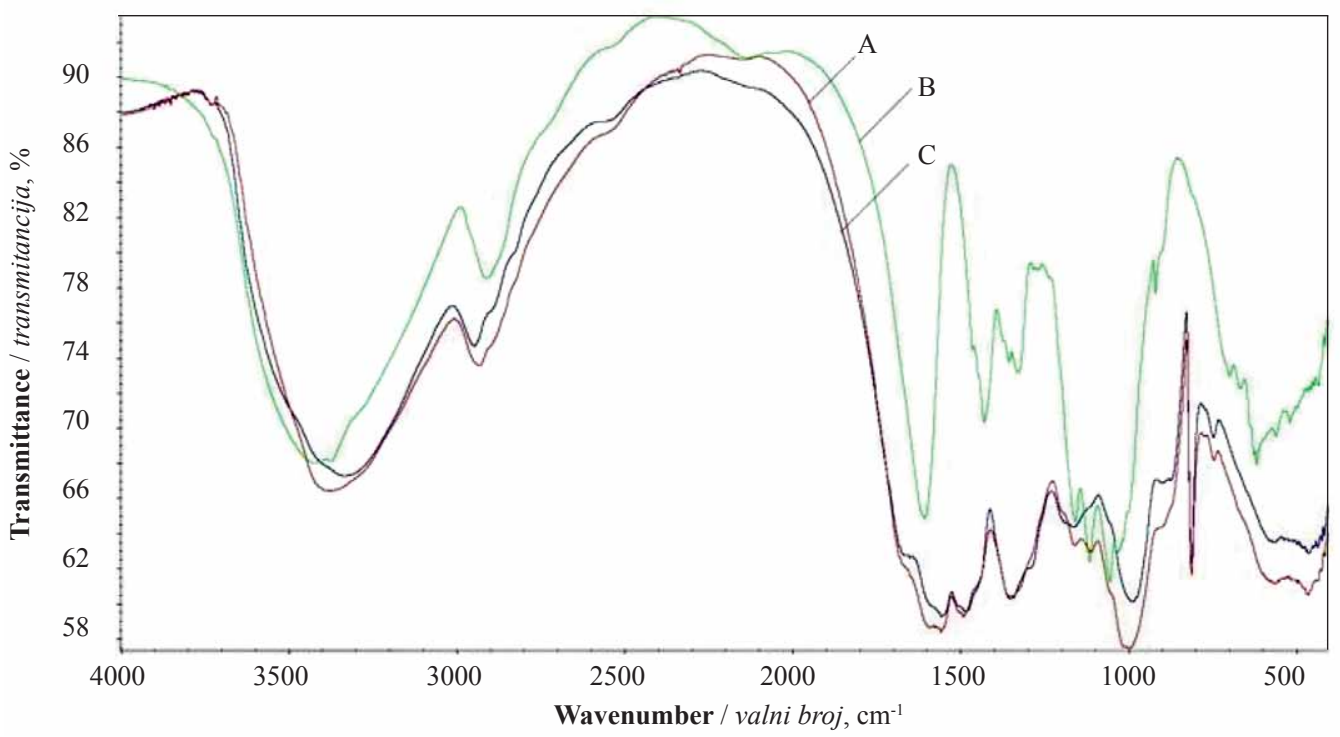

Figure 2 FTIR spectra of: A - modified resin labeled N5; B - nanocellulose; C - unmodified MUF resin

Slika 2. FTIR spektri: A - modificirana smola označena kao N5; B - nanoceluloza; C - nemodificirana MUF smola 


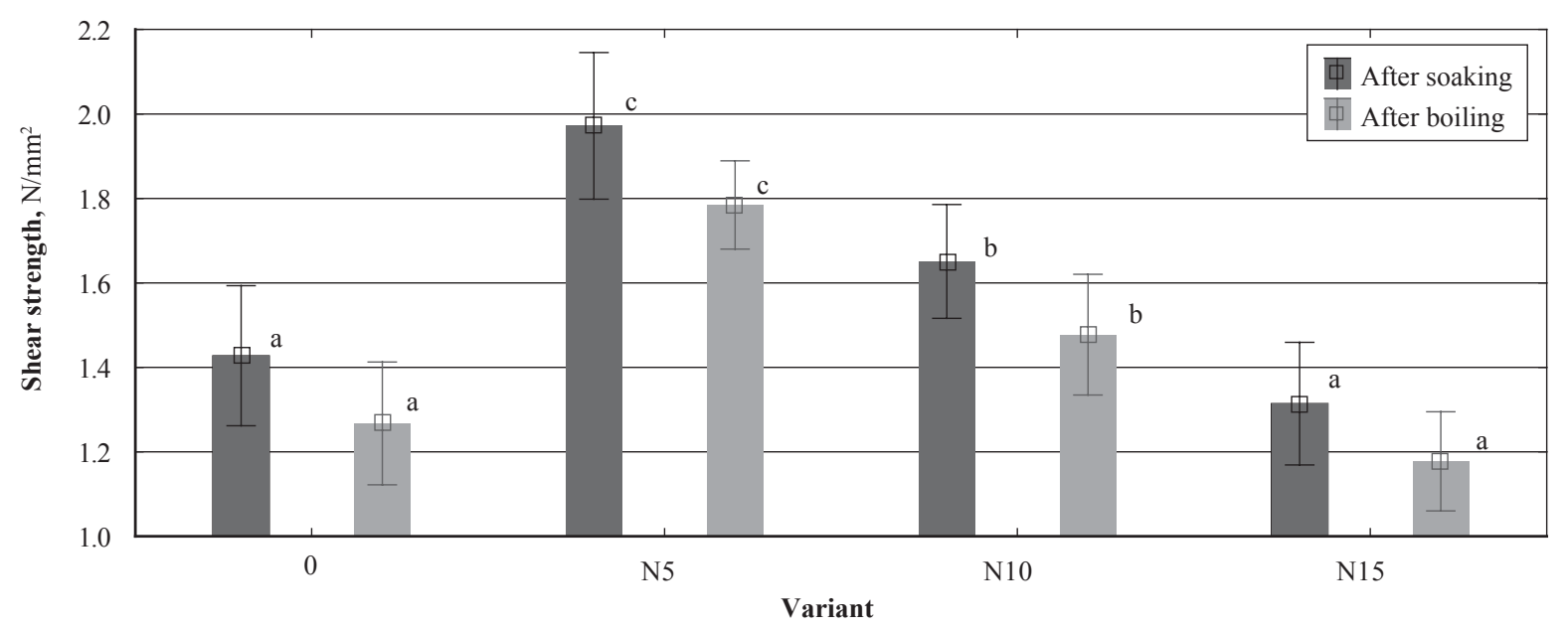

Figure 3 Shear strength of plywood (a, b, c letters indicate homogeneous groups)

Slika 3. Čvrstoća na smik furnirske ploče (a, b i c slova označuju homogene grupe)

transmittance spectra of cured modified and non-modified resins are presented in Figure 2. Spectra of all modified resins regardless of the variant had the same course.

The broad band at $3400 \mathrm{~cm}^{-1}$ was assigned to the $\mathrm{O}-\mathrm{H}$ stretching of hydroxyl groups in each sample. The $\mathrm{C}-\mathrm{H}$ stretching of methylene groups was recorded in the range from $2920 \mathrm{~cm}^{-1}$ to $2890 \mathrm{~cm}^{-1}$ (Luo et al., 2015). The slight difference in intensity of $\mathrm{C}-\mathrm{H}$ band was probably inducted by the hydrogen bonding in MUF and NCC sample. For MUF and MUF+NCC samples, the peak at $1690 \mathrm{~cm}^{-1}$ corresponded to $\mathrm{C}=\mathrm{O}$ groups in amide (Müller et al., 2009; Pandey and Pitman, 2003). In the case of NCC sample, the peak at $1620 \mathrm{~cm}^{-1}$ was assigned to $\mathrm{O}-\mathrm{H}$ vibration of absorbed water (Wulandari et al., 2016). The peak at $1320 \mathrm{~cm}^{-1}$ corresponded to $\mathrm{C}-\mathrm{H}$ and $\mathrm{C}-\mathrm{O}$ vibrations contained in the polysaccharide rings and it was observed at spectra of NCC and MUF+NCC. Spectra of MUF and MUF+NCC were characterized by a peak around 1560 $\mathrm{cm}^{-1}$, which was assigned to the C-N stretching of secondary amines. Moreover, the peak at $1360 \mathrm{~cm}^{-1}$ was assigned to the $\mathrm{C}-\mathrm{N}$ stretching of $\mathrm{CH}_{2}-\mathrm{N}$ witch confirmed presence of amine groups (Luo et al., 2015). The peak at $1060 \mathrm{~cm}^{-1}$ corresponded to vibration from the pyranose ring (spectra of NCC) (Wulandari et al., 2016). In the case of triazine rings, the peak at 1190 $\mathrm{cm}^{-1}$ was observed. It was assigned to $\mathrm{C}-\mathrm{N}$ stretching vibrations (Yuan et al., 2016). Spectra of MUF + NCC was characterized by occurrence of a peaks at 1060 $\mathrm{cm}^{-1}$ and $1120 \mathrm{~cm}^{-1}$, which corresponded to pyranose rings and aliphatic ring, respectively (Luo et al., 2015). These peaks were not observed at MUF spectra. Presumably, it resulted from the fact that interactions occurred between nanocellulose and MUF resin chemical. The peak at $810 \mathrm{~cm}^{-1}$ was assigned to the typical stretching of the triazine ring of melamine and it was observed at spectra of MUF resin and MUF+NCC (Gao et al., 2012; Kandelbauer et al., 2007; Reimschuessel and McDevitt, 1960; Sun et al., 2011).

The transmittance spectra of reference and reinforced adhesive revealed mostly the characteristic functional groups of MUF resins. According to literature, the interfacial bonding of nanocellulose with resins can be attributed to the reaction between the methylol groups of resin and hydroxyl groups of cellulose (Singha and Thakur, 2008).

Glue line quality is one of the most important properties of plywood affecting both its physical and mechanical characteristics (Bekhta et al., 2009a). Thus, the shear strength test was carried out since it is the fundamental indicator of the adhesive performance in plywood panels (Bekhta et al., 2016; Rohumaa et al., 2013). The results of bonding quality are summarized in Figure 3.

In order to fully evaluate how changes in adhesive formulation influenced the mechanical properties of plywood, such as bending strength $(M O R)$ and modulus of elasticity $(M O E)$, investigations were made both parallel and perpendicular to the grains of the face layer. The results are presented in Figure 4.

On the basis of the research conducted, it was confirmed that the key to obtain optimum reinforcement effect was the amount of added nanoparticles (Ferreira 2017). The major improvements in shear strength values were obtained in variants where the percentages of added NCC were 5 and $10 \%$. The best results were observed in case of variant labeled $\mathrm{N} 5$ and the increase was $38 \%$ and $41 \%$ in comparison with reference panels after soaking and after boiling, respectively. The introduction of $10 \mathrm{~g}$ of cellulosic nanoparticles also led to the increase of bonding quality compared to the mixture filled only with flour. As expected based on the previous research, as the amount of nanocellulose increased, the shear strength value constantly decreased (Kawalerczyk et al., 2020b, a; Veigel et al., 2012). Bonding quality of panels labeled N15 was decreased by about $8 \%$ both after soaking and boiling in water. However, all plywood samples met the requirements of EN 314-2 (1993) and their shear strength exceeded $1 \mathrm{~N} / \mathrm{mm}^{2}$.

Mechanical properties, such as modulus of elasticity and bending strength (also called modulus of rupture) of the NCC-modified plywood show significantly 

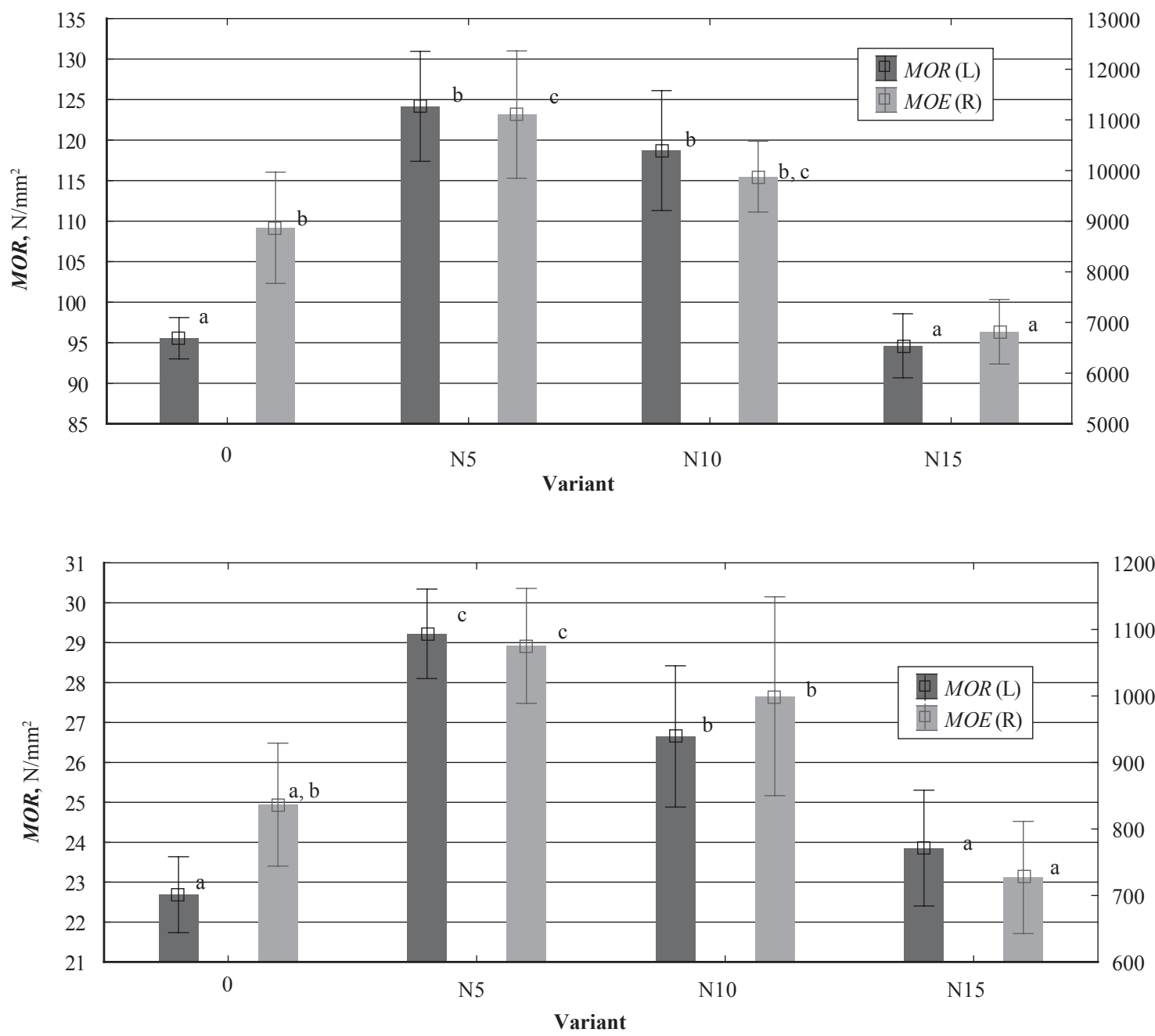

Figure 4 Bending strength $(M O R)$ and modulus of elasticity $(M O E)$ of plywood tested: (a) parallel and (b) perpendicular to grains of face layer (a,b,c letters indicate homogeneous groups)

Slika 4. Čvrstoća na savijanje $(M O R)$ i modul elastičnosti $(M O E)$ ispitivane furnirske ploče: (a) u smjeru žice površinskog sloja i (b) okomito na smjer žice površinskog sloja (a, b i c slova označuju homogene grupe)

higher average values than reference plywood. The most satisfactory results were obtained in case of plywood modified with the smallest addition of nanocellulose. Modulus of elasticity and bending strength increased by approx. $27 \%$ in comparison with control samples. Further addition of modifier at the level of 10 $\mathrm{g}$ also caused an improvement in plywood performance but, as expected from shear strength values, the maximum concentration of nanocellulose caused a notable decrease of panel strength properties.

The addition of nanocellulose to MUF resin shows similar results to the effect on UF resin modification (Kawalerczyk et al., 2020b). Zhang et al. (2011) introduced silane-modified NCC in plywood manufacturing and observed that bonding quality increased by about $24 \%$. Furthermore, investigations of Damásio et al. (2017) showed that the shear strength of a glue line increased by $56 \%$ after the addition of $8 \%$ CNF (cellulose nanofibrils). Ayrilmis et al. (2016a) stated that the enhancement in UF-glue joints strength resulted from their increased ducticility. Veigel et al. (2012) also confirmed the reinforcing nature of nanocellulose. Properties of manufactured particleboards and OSB (oriented strand boards) were improved when the CNF was added to UF resin. The reason for that major reinforcing effect is, as reported by Vineeth et al. (2019), the improvement in fracture energy and fracture toughness. Veigel et al. (2011) showed that the addition of nanocellulose in the amount of $2 \%$ resulted in the increase of the toughening effect up to $45 \%$. The enhancement can be also attributed to the chemical bonding between the methylol groups of resin and the free hydroxyl groups contained in cellulosic chain (Fornué et al., 2011). Moreover, $\mathrm{Hu}$ et al., (2014) confirmed that the presence of cellulose nanocrystals increase the wood-adhesive bonding and interactions. Another aspect leading to the reinforcing effect of the introduction of nanocellulose is the changes in resin morphology. Major fragility of amino resins results from their tendency to develop microcracks (Thomas et al., 2019). They deteriorate the mechanical performance of manufactured materials, and limiting their occurrence has a significant effect on the strength properties of glue lines (Kawalerczyk et al., 2019b). Kawalerczyk et al. (2020a) investigated the effect of nanocellulose addition on phenol-formaldehyde resin morphology. Studies have shown that the modification enhanced the structure of cured resin and made it significantly less 


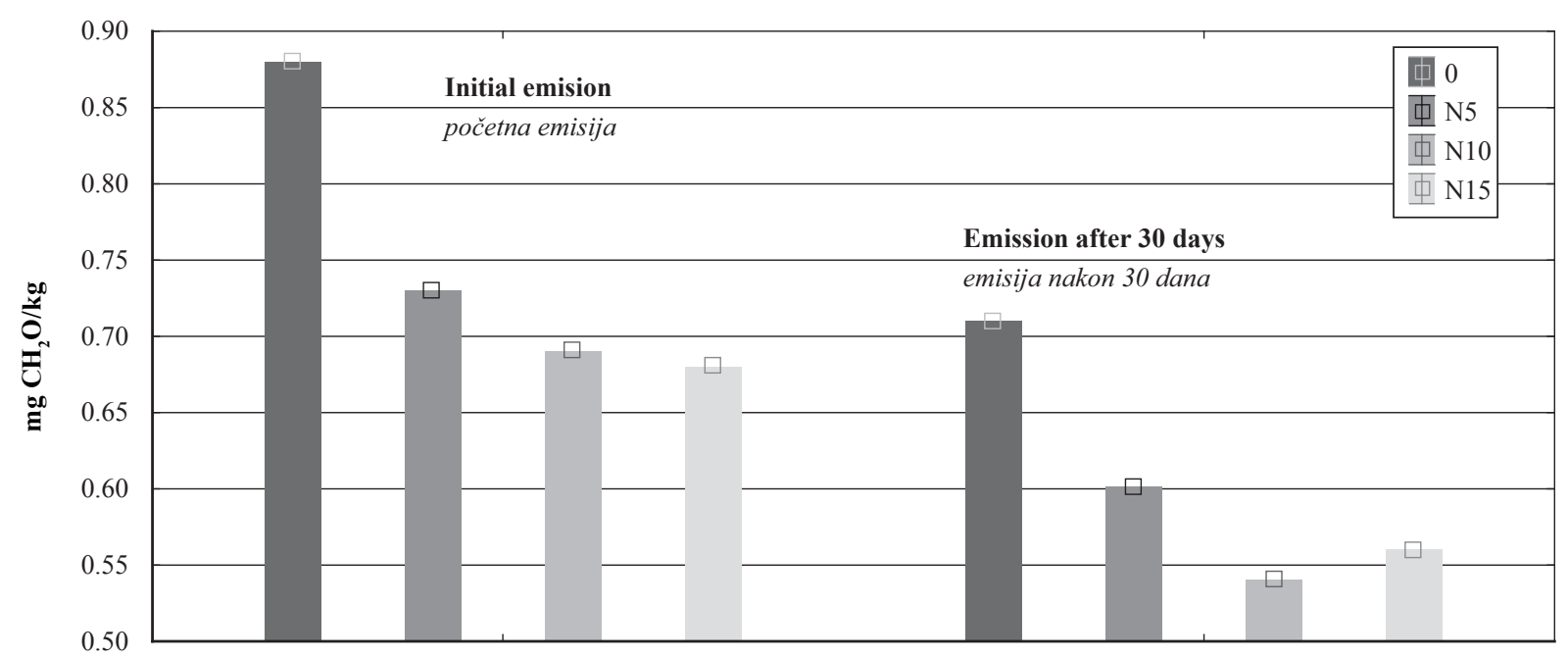

Figure 5 Formaldehyde emission from plywood

Slika 5. Emisija formaldehida iz furnirske ploče

porous, more solid and compact. The deterioration observed in bonding quality, MOR and MOE resulted from too high concentration of nanoparticles, which consequently led to the formation of agglomerates. It has particularly negative effect since the nanofillers act like carriers of stress along the glue line and the occurrence of agglomerates cause the accumulation of load at certain points of the bond (Singha and Thakur, 2008).

A major disadvantage of amino resins is a harmful formaldehyde emission (Dziurka and Mirski, 2014). According to literature, there are three main sources of emitting formaldehyde from adhesives: hydrolytic degradation of cured resin, residual formaldehyde contained in the resin and condensation reaction between hydroxymethyl groups and other aromatic carbon or two hydroxymethyl groups (Tohmura et al., 2001). Since building materials including wood-based materials are considered to be one of the most common sources of formaldehyde emission, it is important to reduce it. The results of $\mathrm{HCHO}$ emissions are presented in Figure 5.

Plywood panels manufactured with the use of NCC-modified resin were characterized by significantly lower formaldehyde emissions. As the concentration of cellulosic nanoparticles increased, the amount of emitted $\mathrm{HCHO}$ was substantially reduced. Thus, the best results were observed in case of variant $\mathrm{N} 15$, where the decrease was $23 \%$. Studies conducted by Zhang et al. (2011) have shown very similar effects. Authors stated that the addition of modified NCC led to reduced $\mathrm{HCHO}$ emission due to physical adsorption and chemisorption. Moreover, Li et al. (2015) hypothesized that the decreased formaldehyde emissions can be attributed to increased viscosity of an adhesive. According to the author's theory, the glue mixture characterized by low viscosity penetrates into the wood pores, which consequently increases the emission of plywood. It was also reported that the monomeric formaldehyde and polyoxymethylene glycols contained in the resin can easily interact with $\mathrm{OH}$ groups of nanoparticles (Candan and Akbulut, 2013; Dudkin et al., 2006).
Furthermore, cellulose itself is able to irreversibly bound formaldehyde in small quantities (Bekhta et al., 2019; Kamath et al., 1985). Another reason for this reduction can be the unique characteristics of nanoparticles such as chemical activity, tremendous surface area or physical properties. Liu and Zhu (2014) explained that the decrease in $\mathrm{HCHO}$ emissions results from the ability of nanoparticles to absorb free formaldehyde from adhesives.

The resin costs are more than $60 \%$ of the total wood-based materials manufacturing costs (Cao et al., 2018). Both the modification of veneer surface and the modification of adhesives are investigated factors that can possibly lead to the reduction of the binding agent consumption. The possibility to reduce the amount of applied resin was determined on the basis of shear strength test and the results are presented in Figure 6.

As the amount of applied glue mixture decreased, the bonding quality also decreased. The shear strength values were reduced since the quantity of applied resin was insufficient to fully and evenly cover the veneer surface (Bekhta and Marutzky, 2007). Introducing nanocellulose in the amount of $5 \mathrm{~g}$ per $100 \mathrm{~g}$ of solid MUF resin had a positive effect on its properties, durability and morphology, and consequently it allowed to reduce adhesive spread rate by $30 \%$. The experimental plywood glued with reference resin mixture in the amount of $170 \mathrm{~g} / \mathrm{m}^{2}$ was characterized by equally good shear strength as panels manufactured with the use of NCC-reinforced adhesive in the amount of $140 \mathrm{~g} / \mathrm{m}^{2}$. The differences between these two variants were not statistically significant and the p-value was 0.999020 and 0.999987 after soaking and after boiling, respectively. However, further decrease of adhesive spread rate led to a notable deterioration in bonding quality, but the results still met the requirements of EN 314-2 (1993). The modification of resin seems to be more effective than surface modification, e.g. veneer compression (Bekhta and Marutzky, 2007). Corresponding results were obtained by Dukarska and Czarnecki (2016) in studies concerning the nano- $\mathrm{SiO}_{2}$ addition to MUPF (melamine-urea-phenol-formaldehyde) adhesive. The 


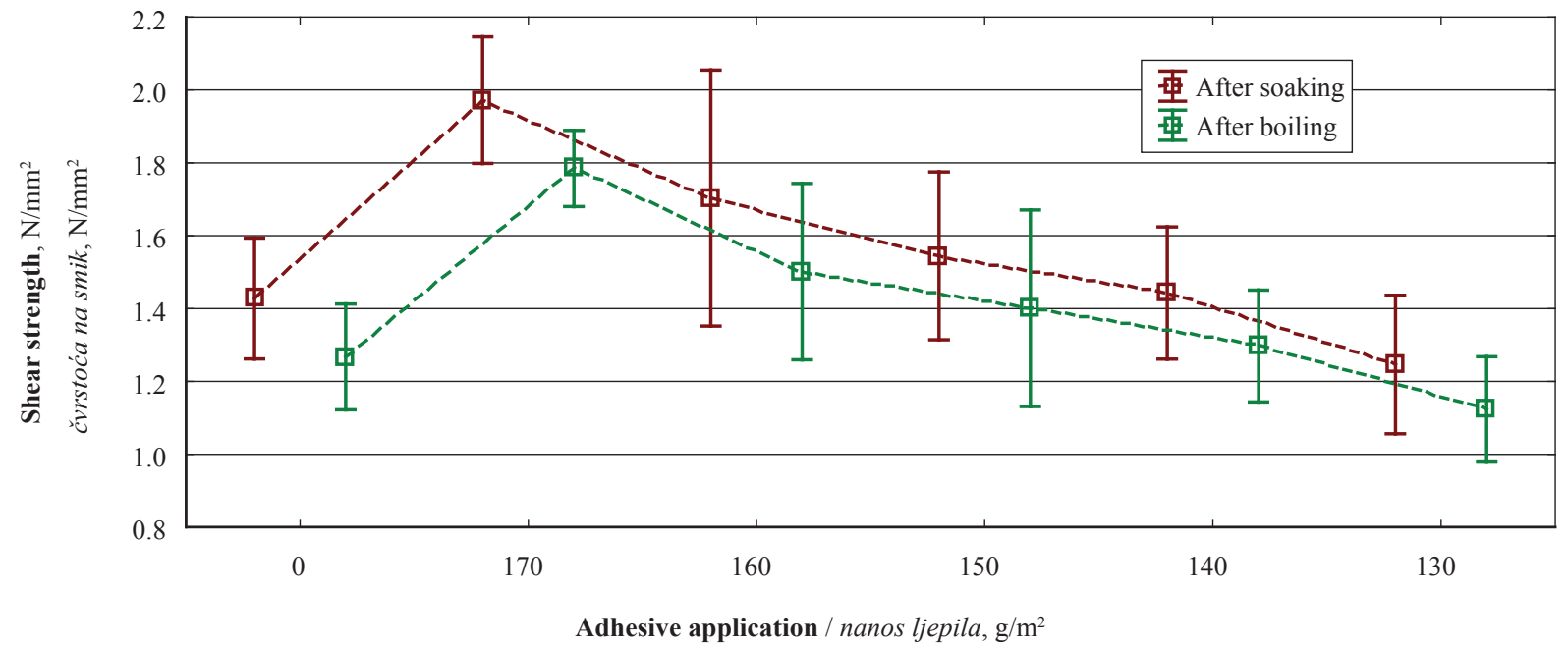

Figure 6 Reduction of adhesive application in manufactured plywood

Slika 6. Smanjenje nanosa ljepila u proizvodnji furnirske ploče

introduction of fumed nanosilica allowed to decrease the resin spread rate in plywood production by $30 \%$. In future, it would be interesting to investigate how the reduction of MUF adhesive consumption influences the emission of free formaldehyde.

\section{CONCLUSIONS}

\section{ZAKLJUČAK}

The time-viscosity dependence showed a significant increase after the addition of nanocellulose. As the amount of added nanomodifier increased, the viscosity values also increased.

The Fourier transform infrared spectroscopy (FTIR) did not show any major changes between experimental and reference samples, thus it did not explain the chemical interaction between nanocellulose and melamine-urea-formaldehyde resin.

The addition of small amounts of nanocellulose ( $5 \mathrm{~g}$ and $10 \mathrm{~g}$ ) led to the improvement in bonding quality and mechanical properties such as modulus of elasticity and bending strength. The best results were obtained in case where the concentration of NCC was up to $5 \mathrm{~g}$ per $100 \mathrm{~g}$ of solid resin.

The MUF adhesive modification with nanocellulose caused a decrease in the amount of emitting formaldehyde.

The addition of nanocellulose allowed the reduction in adhesive consumption by $30 \%$.

\section{Acknowledgements - Zahvala}

We would like to thank Szymon Jagodziński and Jakub Guziak for their help in conducting this research project.

\section{REFERENCES}

\section{LITERATURA}

1. Aras, U.; Kalaycioglu, H.; Husnu, Y.; Bitek, G., 2015: Effects of Ammonium Nitrate on Physico-mechanical properties and formaldehyde content of particleboard.
Procedia - Social and Behavioral Sciences, 195: 21302134.

2. Ayrilmis, N.; Kwon, J.-H.; Lee, S.-H.; Han, T.-H.; Park, C.-W., 2016a: Microfibrillated-cellulose-modified ureaformaldehyde adhesives with different $\mathrm{F} / \mathrm{U}$ molar ratios for wood-based composites. Journal of Adhesion Science and Technology, 30 (18): 2032-2043. https://doi.org/10.1 080/01694243.2016.1175246.

3. Ayrilmis, N.; Lee, Y.-K.; Kwon, J. H.; Han, T.-H.; Kim, H.-J., 2016b: Formaldehyde emission and VOCs from LVLs produced with three grades of urea-formaldehyde resin modified with nanocellulose Building and Environment, 97: 82-87. https://doi.org/10.1016/j.buildenv.2015.12.009.

4. Babicka, M.; Woźniak, M.; Dwiecki, K.; Borysiak, S.; Ratajczak, I., 2020: Preparation of nanocellulose using ionic liquids: 1-propyl-3-methylimidazolium chloride and 1-ethyl-3-methylimidazolium chloride. Molecules, 25 (7): 1544. https://doi.org/10.3390/molecules25071544.

5. Bekhta, P.; Bryn, O.; Sedliacik, J.; Novák, I., 2016: Effect of different fire retardants on birch plywood properties. Acta Facultatis Xylologiae Zvolen, 58 (1): 59. https://doi.org/10.17423/afx.2016.58.1.07.

6. Bekhta, P.; Hiziroglu, S.; Potapova, O.; Sedliacik, J., 2009a: Shear strength of exterior plywood panels pressed at low temperature. Materials, 2 (3): 876-882. https://doi.org/10.3390/ma2030876.

7. Bekhta, P.; Hiziroglu, S.; Shepelyuk, O., 2009b: Properties of plywood manufactured from compressed veneer as building material. Materials \& Design, 30 (4): 947953. https://doi.org/10.1016/j.matdes.2008.07.001.

8. Bekhta, P.; Marutzky, R., 2007: Reduction of glue consumption in the plywood production by using previously compressed veneer. Holz als Roh- und Werkstoff, 65 (1): 87-88. https://doi.org/10.1007/s00107-006-0142-8.

9. Bekhta, P.; Salca, E.-A.; Lunguleasa, A., 2020: Some properties of plywood panels manufactured from combinations of thermally densified and non-densified veneers of different thicknesses in one structure. Journal of Building Engineering, 29: 101116. https://doi.org/10.1016/j.jobe.2019.101116.

10. Bekhta, P.; Sedliačik, J.; Kačík, F.; Noshchenko, G.; Kleinová, A. 2019: Lignocellulosic waste fibers and their application as a component of urea-formaldehyde adhe- 
sive composition in the manufacture of plywood. European Journal of Wood and Wood Products, 77 (4): 495508. https://doi.org/10.1007/s00107-019-01409-8.

11. Candan, Z.; Akbulut, T., 2013: Developing environmentally friendly wood composite panels by nanotechnology. BioResources, 8 (3): 3590-3598. https://doi.org/10.15376/biores.8.3.3590-3598.

12. Cao, Y.; Zhou, X.; Chen, M.; Chen, W.; Yu, P.; Thiphuong, N., 2018: Enhancing resin efficiency in plywood production via DBD plasma treatment and atomized air spray of UF resin. Holzforschung, 72 (12): 1057-1062. https://doi.org/10.1515/hf-2018-0015.

13. Damásio, R. A. P.; Carvalho, A. G.; Gomes, F. J. B.; Carneiro, A.; Ferreira, J. C.; Colodette, J. L., 2017: Effect of $\mathrm{CNC}$ interaction with urea-formaldehyde adhesive in bonded joints of Eucalyptus sp. Scientia Forestalis, 45 (113): 169-176.

14. Derkyi, N. S. A.; Seliyere, D.; Yartey, J. G., 2008: Effect of cassava flour as urea-formaldehyde adhesive extender on the bonding strength of plywood. International Journal of Sciences: Basic and Applied Research, 3 (2): $62-68$.

15. Dudkin, B. N.; Krivoshapkin, V. P.; Krivoshapkina, E. F., 2006: Effect of aluminum oxide nanoparticles on the properties of urea-formaldehyde resin. Russian Journal of Applied Chemistry, 79 (9): 1522-1525. https://doi.org/10.1134/S1070427206090254.

16. Dukarska, D.; Czarnecki, R., 2016: Fumed silica as a filler for MUPF resin in the process of manufacturing water-resistant plywood. European Journal of Wood and Wood Products, 74 (1): 5-14.

https://doi.org/10.1007/s00107-015-0955-4.

17. Dziurka, D.; Mirski, R., 2014: Properties of liquid and polycondensed uf resin modified with pMDI. Drvna industrija, 65 (2): 115-119. https://doi.org/10.5552/drind.2014.1321.

18. Ferreira, J. C., 2017: Synthesis of urea-formaldehyde adhesives with the addition of kraft lignin and nanocrystalline cellulose. PhD Thesis, Federal University of Viçosa, Brasil.

19. Fornué, E. D.; Allan, G. G.; Quiñones, H. J. C.; González, G. T.; Saucedo, J. T., 2011: Fundamental aspects of adhesion between cellulosic surfaces in contact-a review. O Papel, 72 (9): 85-90.

20. Gao, Q.; Shi, S. Q.; Zhang, S.; Li, J.; Wang, X.; Ding, W.; Liang, K.; Wang, J., 2012: Soybean meal based adhesive enhanced by MUF resin. Journal of Applied Polymer Science, 125 (5): 3676-3681.

https://doi.org/10.1002/app.36700.

21. Gardner, D.; Oporto, G.; Mills, R.; Said, M.; Azizi Samir, M. A. S., 2008: Adhesion and surface issues in cellulose and nanocellulose. Journal of Adhesion Science and Technology, 22: 545-567. https://doi.org/10.1163/156856108X295509.

22. Gonçalves, M.; Paiva, N. T.; Ferra, J. M.; Martins, J.; Magalhães, F. D.; Carvalho, L., 2019: Chemical composition of melamine-urea-formaldehyde (MUF) resins assessed by near-infrared (NIR) spectroscopy. International Journal of Adhesion and Adhesives, 93: 102327. https://doi.org/10.1016/j.ijadhadh.2019.01.021.

23. Henriksson, M.; Berglund, L., 2007: Structure and properties of cellulose nanocomposite films containing melamine formaldehyde. Journal of Applied Polymer Science, 106: 2817-2824. https://doi.org/10.1002/app.26946.

24. Hong, M.-K.; Park, B.-D., 2017: Effect of urea-formaldehyde resin adhesive viscosity on plywood adhesion.
Journal of The Korean Wood Science and Technology, 45 (2): 223-231.

25. Hu, K.; Kulkarni, D. D.; Choi, I.; Tsukruk, V. V., 2014: Graphene-polymer nanocomposites for structural and functional applications. Progress in Polymer Science, 39 (11): 1934-1972. Journal of The Korean Wood Science and Technology 10.1016/j.progpolymsci.2014.03.001.

26. Hulla, J.; Sahu, S.; Hayes, A., 2015: Nanotechnology: History and future. Human \& Experimental Toxicology, 34 (12): 1318-1321.

https://doi.org/10.1177/0960327115603588.

27. Iotti, M.; Gregersen, Ø. W.; Moe, S.; Lenes, M., 2011: Rheological studies of microfibrillar cellulose water dispersions. Journal of Polymers and the Environment, 19 (1): 137-145. https://doi.org/10.1007/s10924-010-0248-2.

28. Janardhnan, S.; Sain, M., 2011: Isolation of cellulose nanofibers: effect of biotreatment on hydrogen bonding network in wood fibers. International Journal of Polymer Science, vol. 2011, Article ID 279610, 6 pages. https://doi.org/10.1155/2011/279610.

29. Jóźwiak, M., 2018: Ethylene glycol modification of waste-free adhesive melamine-urea-formaldehyde resins for the production of waterproof plywood. Annals of Warsaw University of Life Sciences-SGGW. Forestry and Wood Technology, 104: 18-21.

30. Kamath, Y. K.; Hornby, S. B.; Weigmann, H.-D., 1985: Irreversible chemisorption of formaldehyde on cotton cellulose. Textile Research Journal, 55 (11): 663-666. https://doi.org/10.1177/004051758505501106.

31. Kamoun, C.; Pizzi, A.; Zanetti, M., 2003: Upgrading melamine-urea-formaldehyde polycondensation resins with buffering additives. I. The effect of hexamine sulfate and its limits. Journal of Applied Polymer Science, 90 (1): 203-214. https://doi.org/10.1002/app.12634.

32. Kandelbauer, A.; Despres, A.; Pizzi, A.; Taudes, I., 2007: Testing by fourier transform infrared species variation during melamine-urea-formaldehyde resin preparation. Journal of Applied Polymer Science, 106 (4): 2192-2197. https://doi.org/10.1002/app.26757.

33. Kawalerczyk, J.; Dziurka, D.; Mirski, R.; Grześkowiak, W., 2019a: The effect of veneer impregnation with a mixture of potassium carbonate and urea on the properties of manufactured plywood. Drewno, 203: 107-116. https://doi.org/10.12841/wood.1644-3985.281.12.

34. Kawalerczyk, J.; Dziurka, D.; Mirski, R.; Siuda, J.; Szentner, K., 2020a: The effect of nanocellulose addition to phenol-formaldehyde adhesive in water-resistant plywood manufacturing. BioResources, 15 (3): 5388-5401. https://doi.org/10.15376/biores.15.3.5388-5401.

35. Kawalerczyk, J.; Dziurka, D.; Mirski, R.; Szentner, K., 2020b: Properties of plywood produced with urea-formaldehyde adhesive modified with nanocellulose and microcellulose. Drvna industrija, 71 (1): 61-67. https://doi.org/10.5552/drvind.2020.1919.

36. Kawalerczyk, J.; Dziurka, D.; Mirski, R.; Trociński, A., 2019b: Flour fillers with urea-formaldehyde resin in plywood. BioResources, 14 (3): 6727-6735. https://doi.org/10.15376/biores.14.3.6727-6735.

37. Kawalerczyk, J.; Siuda, J.; Mirski, R.; Dziurka, D., 2020c: Hemp flour as a formaldehyde scavenger for melamine-urea-formaldehyde adhesive in plywood production. BioResources, 15 (2): 4052-4064. https://doi. org/10.15376.biores.15.2.4052-4064.

38. Kawalerczyk, J.; Dziurka, D.; Mirski, R.; Siuda, J., 2021: The reduction of adhesive application in plywood manufacturing by using nanocellulose-reinforced urea-formal- 
dehyde resin. Journal of Applied Polymer Science, e49834. https://doi.org/10.1002/app.49834.

39. Lei, H.; Frazier, C., 2015: Curing behavior of melamineurea-formaldehyde (MUF) resin adhesive. International Journal of Adhesion and Adhesives, 119. https://doi.org/10.1016/j.ijadhadh.2015.06.013.

40. Li, X.; Li, J.; Li, J.; Gao, Q., 2015: Effect of sepiolite filler in malamine-urea-formaldehyde resin on the properties of three-ply plywood. BioResources, 10 (4): 66246634. https://doi.org/10.15376/biores.10.4.6624-6634.

41. Liu, Y.; Zhu, X. 2014: Measurement of formaldehyde and VOCs emissions from wood-based panels with nanomaterial-added melamine-impregnated paper. Construction and Building Materials, 66: 132-137. https://doi.org/10.1016/j.conbuildmat.2014.05.088.

42. Luo, J.; Zhang, J.; Luo, J.; Li, J.; Gao, Q., 2015: Effect of melamine allocation proportion on chemical structures and properties of melamine-urea-formaldehyde resins. BioResources, 10 (2): 3265-3276.

https://doi.org/10.15376/biores.10.2.3265-3276.

43. Mahrdt, E.; Pinkl, S.; Schmidberger, C.; van Herwijnen, H. W.; Veigel, S.; Gindl-Altmutter, W., 2016: Effect of addition of microfibrillated cellulose to urea-formaldehyde on selected adhesive characteristics and distribution in particle board. Cellulose, 23 (1): 571-580. https://doi.org/10.1007/s10570-015-0818-5.

44. Majewski, A., 2019: Furniture use safety at early design stage. Annals of Warsaw University of Life SciencesSGGW. Forestry and Wood Technology, 107: 84-92.

45. Mirski, R.; Dziurka, D.; Łęcka, J., 2011: Potential of shortening pressing time or reducing pressing temperature for plywood resinated with PF resin modified using alcohols and esters. European Journal of Wood and Wood Products, 69 (2): 317-323. https://doi.org/10.1007/s00107-010-0436-8.

46. Mirski, R.; Kawalerczyk, J.; Dziurka, D.; Siuda J.; Wieruszewski, M., 2020: The application of oak bark powder as a filler for melamine-urea-formaldehyde adhesive in plywood manufacturing. Forests, 11 (12): 1249. https://doi.org/10.3390/f11121249.

47. Müller, G.; Schöpper, C.; Vos, H.; Kharazipour, A.; Polle, A., 2009: FTIR-ATR spectroscopic analyses of changes in wood properties during particle-and fibreboard production of hard-and softwood trees. BioResources, 4 (1): 49-71.

48. Ong, H. R.; Khan, M. M. R.; Prasad, D. R.; Yousuf, A.; Chowdhury, M. N. K., 2018: Palm kernel meal as a melamine urea formaldehyde adhesive filler for plywood applications. International Journal of Adhesion and Adhesives, 85: 8-14. https://doi.org/10.1016/j.ijadhadh.2018.05.014.

49. Pandey, K. K.; Pitman, A. J., 2003: FTIR studies of the changes in wood chemistry following decay by brownrot and white-rot fungi. International Biodeterioration \& Biodegradation, 52 (3): 151-160. https://doi.org/10.1016/S0964-8305(03)00052-0.

50. Réh, R.; Igaz, R.; Krišt’ák, L.; Ružiak, I.; Gajtanska, M.; Božíková, M.; Kučerka, M., 2019: Functionality of beech bark in adhesive mixtures used in plywood and its effect on the stability associated with material systems. Materials, 12 (8): 1298. https://doi.org/10.3390/ma12081298.

51. Reimschuessel, H. K.; McDevitt, N. T., 1960: Infrared spectra of some 1, 3, 5-triazine derivatives. Journal of the American Chemical Society, 82 (14): 3756-3762. https://doi.org/10.1021/ja01499a071.

52. Rohumaa, A.; Hunt, C. G.; Hughes, M.; Frihart, C. R.; Logren, J., 2013: The influence of lathe check depth and orientation on the bond quality of phenol-formaldehydebonded birch plywood. Holzforschung, 67 (7): 779-786. https://doi.org/10.1515/hf-2012-0161.

53. Sellers, T., 1985: Plywood and Adhesive Technology. CRC Press.

54. Shahbazi, M.-A.; Hamidi, M.; Mäkilä, E. M.; Zhang, H.; Almeida, P. V.; Kaasalainen, M.; Salonen, J. J.; Hirvonen, J. T.; Santos, H. A., 2013: The mechanisms of surface chemistry effects of mesoporous silicon nanoparticles on immunotoxicity and biocompatibility. Biomaterials, 34 (31): 7776-7789. https://doi.org/10.1016/j.biomaterials.2013.06.052.

55. Singha, A. S.; Thakur, V. K., 2008: Fabrication and study of lignocellulosic hibiscus sabdariffa fiber reinforced polymer composites. BioResources, 3 (4): 1173-1186.

56. Sun, Q.-N.; Hse, C.-Y.; Shupe, T. F., 2011: Characterization and performance of melamine enhanced urea formaldehyde resin for bonding southern pine particleboard. Journal of Applied Polymer Science, 119 (6): 3538-3543. https://doi.org/10.1002/app.33023.

57. Sydor, M.; Rogoziński, T.; Stuper-Szablewska, K. M.; Starczewski, K., 2020: The accuracy of holes drilled in the side surface of plywood. BioResources, 15 (1): 117 129. https://doi.org/10.15376/biores.15.1.117-129.

58. Szczesna-Antczak, M.; Kazimierczak, J.; Antczak, T., 2012: Nanotechnology - Methods of manufacturing cellulose nanofibres. Fibres and Textiles in Eastern Europe, 20: 8-12.

59. Thomas, S.; Mishra, R. K.; Asiri, A. M., 2019: Sustainable Polymer Composites and Nanocomposites, Springer.

60. Tohmura, S.; Inoue, A.; Sahari, S. H., 2001: Influence of the melamine content in melamine-urea-formaldehyde resins on formaldehyde emission and cured resin structure. Journal of Wood Science, 47 (6): 451-457. https:// doi.org/10.1007/BF00767897.

61. Veigel, S.; Müller, U.; Keckes, J.; Obersriebnig, M.; Gindl-Altmutter, W., 2011: Cellulose nanofibrils as filler for adhesives: effect on specific fracture energy of solid wood-adhesive bonds. Cellulose, 18 (5): 1227. https://doi.org/10.1007/s10570-011-9576-1.

62. Veigel, S.; Rathke, J.; Weigl, M.; Gindl-Altmutter, W., 2012: Particle board and oriented strand board prepared with nanocellulose-reinforced adhesive. Journal of $\mathrm{Na}$ nomaterials, 2012: 158503. https://doi.org/10.1155/2012/158503.

63. Vineeth, S. K.; Gadhave, R. V.; Gadekar, P. T., 2019: Nanocellulose applications in wood adhesives. Open Journal of Polymer Chemistry, 9 (4): 63-75. https://doi.org/10.4236/ojpchem.2019.94006.

64. Wegner, T. H.; Jones, P. E., 2006: Advancing cellulosebased nanotechnology. Cellulose, 13 (2): 115-118. https://doi.org/10.1007/s10570-006-9056-1.

65. Wegner, T.; Jones, P., 2005: Nanotechnology for the forest products industry. Wood and Fiber Science, 37 (4): 549-551.

66. Wulandari, W. T.; Rochliadi, A.; Arcana, I. M., 2016: Nanocellulose prepared by acid hydrolysis of isolated cellulose from sugarcane bagasse. Materials Science and Engineering, 107: 012045. https://doi.org/10.1088/1757-899X/107/1/012045.

67. Yamane, C.; Aoyagi, T.; Ago, M.; Sato, K.; Okajima, K.; Takahashi, T., 2006: Two different surface properties of regenerated cellulose due to structural anisotropy. Polymer Journal, 38 (8): 819-826. https://doi.org/10.1295/polymj.PJ2005187.

68. Yuan, X.; Luo, K.; Zhang, K.; He, J.; Zhao, Y.; Yu, D., 2016: Combinatorial vibration-mode assignment for the 
..... Kawalerczyk, Dziurka, Mirski, Siuda, Babicka: Possibility of Use of NCC-Reinforced...

FTIR spectrum of crystalline melamine: A strategic approach toward theoretical IR vibrational calculations of triazine-based compounds. The Journal of Physical Chemistry, 120 (38): 7427-7433.

https://doi.org/10.1021/acs.jpca.6b06015.

69. Zhang, H.; Zhang, J.; Song, S.; Wu, G.; Pu, J., 2011: Modified nanocrystalline cellulose from two kinds of modifiers used for improving formaldehyde emission and bonding strength of urea-formaldehyde resin adhesive. BioResources, 6 (4): 4430-4438.

70. ***EN 310, 1993: Wood-based panels. Determination of modulus of elasticity in bending and of bending strength. European Committee for Standardization, Brussels.

71. ***EN 314-1, 2004: Plywood. Bonding quality. Test methods. European Committee for Standardization, Brussels.

72. ***EN 314-2, 1993: Plywood. Bonding quality. Requirements. European Committee for Standardization, Brussels.
73. ***EN 717-3, 1996: Wood-based panels - Determination of formaldehyde release. Part 3: Formaldehyde release by the flask method.

\section{Corresponding address:}

\section{JAKUB KAWALERCZYK}

Poznań University of Life Sciences

Faculty of Forestry and Wood Technology

Department of Wood-Based Materials

Poznan, POLAND

e-mail: jakub.kawalerczyk@up.poznan.pl 